\title{
An Unusual Combination of Acute Pancreatitis Etiologies: Hypertriglyceridemia and Carbamazepine Use
}

\author{
Akut Pankreatit Etiyolojilerinin Sıra Dışı Bir Kombinasyonu: \\ Hipertrigliseridemi ve Karbamazepin Kullanımı
}

\begin{abstract}
(D) Sevgi Herek, (D Celalettin Herek, (D) Mediha İrem Onar, (D Pervin Gümülcineli, (D Ömer Saçli, (D) Ahmet Engin Atay
\end{abstract}

University of Health Sciences, İstanbul Bağcılar Training and Research Hospital, Clinic of Internal Medicine, İstanbul, Turkey

\section{Abstract}

Among several etiologic factors of acute pancreatitis (AP), hypertriglyceridemia and chronic drug use are less frequent causes, responsible for approximately $10 \%$ of all cases. Our aim is to present a case of AP who had hypertriglyceridemia and was receiving carbamazepine.

Keywords: Akut pancreatitis, hypertriglyceridemia, carbamazepine use

\section{Introduction}

Acute pancreatitis (AP) is one of the most common gastrointestinal disorder that needs hospitalization with a mortality rate of $30 \%$ in mild to severe forms (1). Typical abdominal pain, elevated pancreatic enzymes (amylase and lipase) and characteristic tomographic findings are the mainstay in the diagnosis. The most common causes of AP are cholelitiasis and alcohol consumption. However, hypertriglyceridemia, drug use and antimicrobial agents are also involved in the etiology of AP. Serum levels of triglyceride in hypertriglyceridemia related AP usually exceed $500 \mathrm{mg} / \mathrm{dL}$ or even $1000 \mathrm{mg} /$ $\mathrm{dL}$ (2). The pathogenesis of hypertriglyceridemia related AP is lipotoxicity which is caused by breakdown of triglycerides to free fatty acids by pancreatic lipase (3). Additionally, more than hundreds of drugs including

\section{Ozz}

Birçok farklı etiyolojik faktörün neden olduğu akut pankreatit (AP) olgularının \%10'dan, hipertrigliseridemi ve kronikilaç kullanımı sorumludur. Amacımı hipertrigliseritemisi olan ve karbamazepin kullanan hastada gelişen AP olgusunu sunmaktır.

Anahtar kelimeler: Akut pankreatit, hipertrigliseridemi, karbamazepin kullanımı

antihypertensives, antibiotics, anti-inflammatory drugs and antiepileptics are accused for AP (1). We present a case of AP who had hypertriglyceridemia and was receiving carbamazepin for epilepsy.

\section{Case Report}

A 58 year women who had no chronic disorder, except epilepsy, admitted to emergency department with abdominal pain and nause-vomitting lasting for 5 hours. She has been using carbamazepin for 10 years, and also had a history of AP episode 5 years ago. Except right upper quadrant abdominal pain, she had no complaint. First blood sample of the patient was lipemic which precludes analysis of biochemical variables (Figure 1). At this sample, lipase: $878 \mathrm{U} / \mathrm{L}$ amilase: $485 \mathrm{U} / \mathrm{L}$, triglyceride: $1420 \mathrm{mg} / \mathrm{dL}$ and C-reactive protein: $29 \mathrm{mg} / \mathrm{L}$. The other 
biochemical variables and hemogram parameters were all in normal range. No sign of cholelithiasis or dilatation on choledoch was observed. Tomographic examination revealed interstitial pancreatitis and fluid collection around inflammation area, but no pancreatic necrosis or hemorrhage (Figure 2). The patient was diagnosed as drug and hypertriglyceridemia related AP. Antiepileptic medication was switched to levetirasetam which is less likely to cause pancreatic inflammation. Until abdominal pain of the patients recovered, oral nutrition was ceased and intravenous hydration was administered. After an uneventfull hospitalization for 5 days, clinical and biochemical improvements were achieved, and the patient was discharged by recommending out patient clinical follow-up.
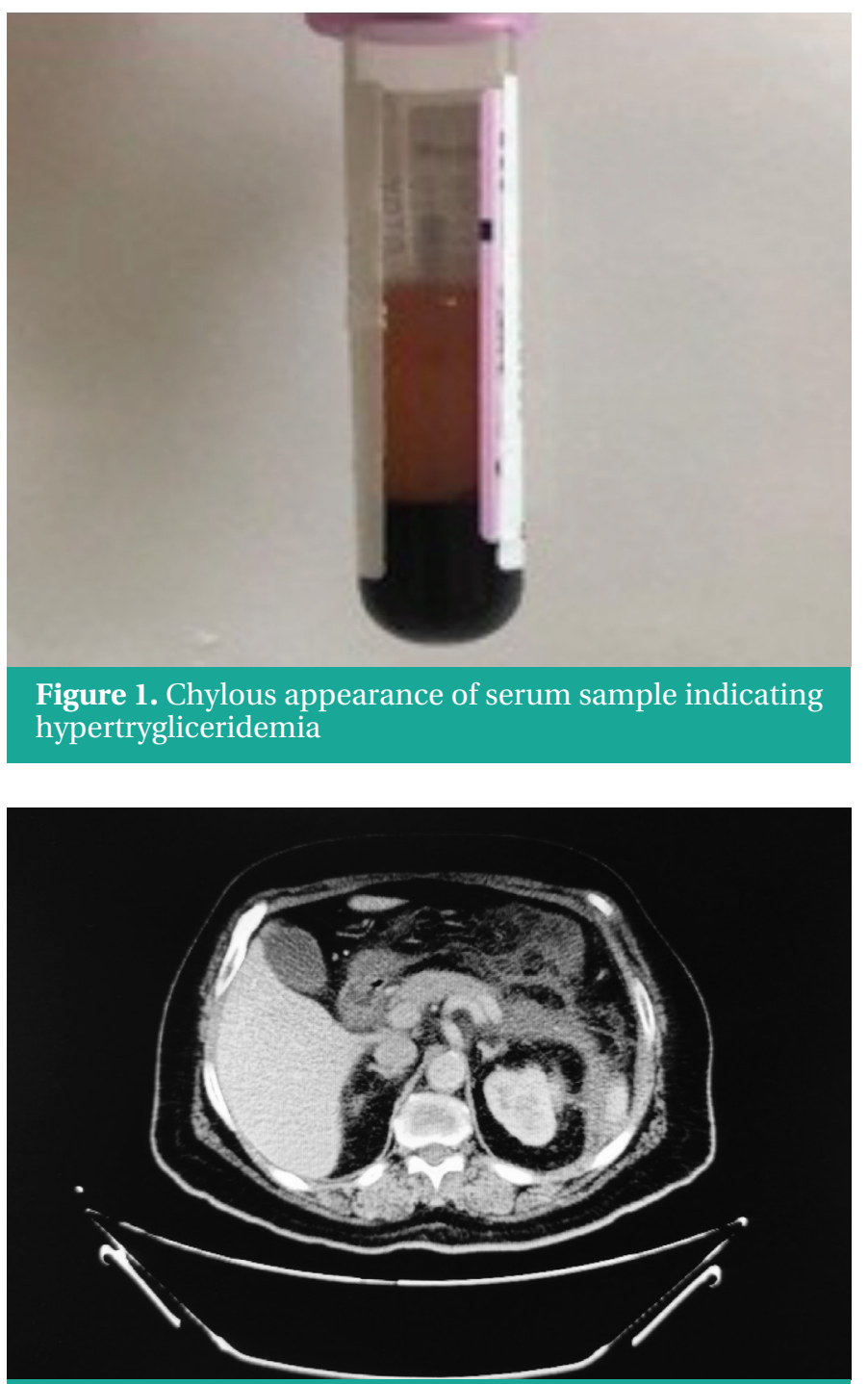

Figure 2. Tomographic examination showing interstitiel pancreatitis and fluid collection around inflammation

\section{Discussion}

Acute inflammation of pancreatitis is associated with over 270,000 hospitalizations and costs up to 2.6 billion dollars per year (4). The outcome of AP may range from self-resolving disorder to multiorgan failure, or even death. Hypertriglyceridemia related AP is at the third rank, following gallstones and alcohol, with a frequency of 1-7\% of patients with AP (2). Bessembinders et al. (5) showed that AP risk of patients with triglyceride $>1000 \mathrm{mg} / \mathrm{dL}$ is $8 \%$. They also demonstrated that the risk logaritmically rises if there is comorbidity like diabetes, obesity, alcohol intake or chronic drug use. Although the clinical presentation of hypertriglyceridemia related AP is similar to other causes related AP, the risk of complications is higher (6). Clinicians should be aware of the fact that high triglyceride levels ( $>500 \mathrm{mg} / \mathrm{dL}$ ) may supress the release of pancreatic enzymes and may cause confusion in the diagnosis of AP (7). Nevertheless, authors recommend similar therapeutic approach to patients with hypertriglyceridemia induced AP, including cessation of oral intake, fluid repletion, opoid analgesia and rapidly decreasing serum triglyceride levels. In the past few decades, some authors have suggested plasmapheresis or combination of insulin and heparin in the management of hypertriglyceridemia induced AP (8). And also minimizing other risk factors of AP is essential like discontinuation of drugs which may trigger recurrence of AP.

On the otherhand, because it is difficult to establish a cause and effect relationship between drug and pancreatitis, controversies exist in the diagnosis and the treatment of drug induced AP. Therefore, case reports rather than randomized clinical trials dominate the literature. Majority of reports support the belief that cessation of suspected drug plays crucial role, and the patients experience rapid symptom relief. The Naranjo Algorithm (Table 1) is used to determine the probability of a change in the clinical status of a patient that is related to drug use rather than other factors (9). Our patient had a final score of 6 meaning that an adverse drug reaction which caused AP is probable. Thus, carbamazepine was switched to a newer and relatively safer antiepyleptic drug "Levetiracetam" (10). In our patient, symtomps declined after levetiracetam therapy initiated. Drug or hypertriglyceridemia related AP is less frequently observed which may cause delay in the diagnosis of the disorder. The diagnosis of AP is established after excluding other etiologic factors. Carbamazepine induced pancreatitis is related to clinical situation and additional risk factors of $\mathrm{AP}$, but not the dose or the duration of the medication. 
Table 1. Naranjo algorithm (probability scoring of acute pancreatitis)

Interpretation of the total score:

9 or more, ADR highly probable,

5 to 8 ADR is probable,

1 to 4 , ADR is possible,

0 or less, ADR is doubtful

1. Are there previous conclusive reports on this $\quad+1 \quad 0$ reaction?

2. Did the adverse event appear after the suspected $\quad \begin{array}{lll}-1 & -1\end{array}$ drug was administered?

3. Did the adverse reaction improve when the drug was $\quad+1 \quad 0$

discontinued or a specific antagonist was administered?

4. Did the adverse reaction reappear when the drug was +2 $\quad-1$ re-administered?

5. Are there alternative causes (other than the drug) that $-1 \quad+2$ could on their own have caused the reaction?

6. Did the reaction re-appear when a placebo was $\quad-1 \quad+1$ given?

7. Was the drug detected in the blood (or other fluids) in $\quad+1 \quad 0$ a concentration to be toxic?

8. Was the reaction more severe when the dose was increased, or less severe when the dose was decreased?

9. Did the patient have a similar reaction on the same or $\quad+1 \quad 0$ similar drugs in any previous exposure?

10. Was the adverse event confirmed by any objective $\quad+1 \quad 0$ evidence?

ADR: Adverse drug reaction

Hypertriglyceridemia as seen in this case, may enhance the risk of AP for the patients who have been receiving carbamazepin. Although some cases require individualization in the management of the disorder, general approach to AP with different etiologies is similar. Patients with high risk of AP should be identified, and the risk factors like high triglyceride should be appropriately treated or drugs associated with high incidence of AP should be discontinued. In conclusion, clinicians should consider initiating antiepileptic or other drug groups with low risk for pancreatitis to patients who had a history or additional risk factor for AP.

\section{Ethics}

Informed Consent: Written consent was received from the patient.
Peer-review: Externally peer-reviewed.

\section{Authorship Contributions}

Concept: S.H., M.İ.O., Design: S.H., P.G., Ö.S., C.H., Data Collection or Processing: S.H., C.H., A.E.A., Analysis or Interpretation: A.E.A., Ö.S., P.G., Literature Search: S.H., C.H., A.E.A., Writing: S.H., P.G., Ö.S., C.H.

Conflict of Interest: Authors declare that there is no conflict of interest with regard to this manuscript.

Financial Disclosure: No financial support was received from a person or a company for writing this case report.

\section{References}

1. Farkas N, Hanák L, Mikó A, Bajor J, Sarlós P, Czimmer J, et al. A Multicenter, International Cohort Analysis of 1435 Cases to Support Clinical Trial Design in AcutePancreatitis. Front Physiol 2019;10:1092.

2. Brown WV, Goldberg IJ, Young SG. JCL Roundtable: Hypertriglyceridemia due to defects in lipoprotein lipase function. J Clin Lipidol 2015;9:274-280.

3. Timilsina S, Timilsina S, Mandal A, Paudel R, Gayam V. Triad of Diabetic Ketoacidosis, Hypertriglyceridemia, and AcutePancreatitis: Severity of Acute Pancreatitis May Correlate with the Level of Hypertriglyceridemia. Cureus 2019;11:e4930.

4. Fagenholz PJ, Castillo CF, Harris NS, Pelletier AJ, Camargo CA. Increasing United States hospital admissions for acute pancreatitis, 1988-2003. Ann Epidemiol 2007;17:491-497.

5. Bessembinders K, Wielders J, van de Wiel A. Severe hypertriglyceridemia influenced by alcohol (SHIBA). Alcohol Alcohol 2011;46:113-116.

6. Kuchay MS, Farooqui KJ, Bano T, Khandelwal M, Gill H, Mithal A. Heparin and insulin in the management of hypertriglyceridemiaassociated pancreatitis: case series and literature review. Arch Endocrinol Metab 2017;61:198-201.

7. Scherer J, Singh VP, Pitchumoni CS, Yadav D. Issues in hypertriglyceridemic pancreatitis: an update. J Clin Gastroenterol 2014;48:195-203.

8. Garg R, Rustagi T. Management of Hypertriglyceridemia Induced AcutePancreatitis. Biomed Res Int 2018;2018:4721357.

9. Naranjo CA, Busto U, Sellers EM, Sandor P, Ruiz I, Roberts EA, et al. A method for estimating the probability of adverse drug reactions. Clin Pharmacol Ther 1981;30:239-245.

10. Briggs DE, French JA. Levetiracetam safety profiles and tolerability in epilepsy patients. Expert Opin Drug Saf 2004;3:415-424. 